\title{
ANALISIS MANFAAT KOPERASI DAN TINGKAT PARTISIPASI ANGGOTA KOPERASI SIMPAN PINJAM (KSP) SUBUR MAKMUR SEJAHTERA KECAMATAN SEPUTIH BANYAK KABUPATEN LAMPUNG TENGAH
}

\author{
(Analysis of Cooperative Benefits and Participation Level of Credit Cooperative (KSP) Subur Makmur \\ Sejahtera Members in Seputih Banyak Central Lampung Regency)
}

Dwi Febrina, Dyah Aring Hepiana Lestari, dan Indah Nurmayasari

Jurusan Agribisnis, Fakultas Pertanian, Universitas Lampung, Jl. Prof. Dr. Soemantri Brojonegoro No. 1 Bandar Lampung 35141, Telp 085279792288, e-mail: dwifebrina1@ gmail.com

\begin{abstract}
This research aims to analyze the economic and noneconomic benefits received by the members, the participation level of cooperative members and affecting factors. This research was purposively conducted at KSP Subur Makmur Sejahtera, Seputih Banyak, Central Lampung Regency from January to February 2018 with 48 respondents randomly taken by using Simple Random Sampling method. Data were collected by using a survey method and were analyzed descriptively using Customer Satisfaction Index (CSI) and Seemingly Unrelated Regressions (SUR). The results showed that the average of economic benefits received was Rp789,05.,62 per year, and noneconomic benefits received as the satisfaction level of cooperative members was classified at the level of satisfied members. The participation level of the cooperative members attending annual meeting, paying compulsory savings, and utilizing the cooperative enterprises were each considered as average, low, and high category. Factors which affected members to participate in attending annual meeting were age, formal and nonformal education, the number of dependent family members, noneconomic benefits, distance, and members' perception. Mean while formal education, noneconomic benefits, and distance affected the participation level of compulsory savings payment,. Lastly, ages, formal and nonformal education, the number of dependent family members, economic benefits, and distance affected the utilization of cooperative enterprises.
\end{abstract}

Key words : cooperative, members, benefits, participation

\section{PENDAHULUAN}

Salah satu cita-cita Bangsa Indonesia sebagaimana disebutkan dalam pembukaan Undang-Undang Dasar 1945 adalah menyejahterakan seluruh rakyat. Akan tetapi, saat ini banyak masyarakat yang masih hidup di bawah garis kemiskinan. Menurut Badan Pusat Statistik (2017), pada bulan September 2017 angka kemiskinan Indonesia mencapai 26,58 juta jiwa dengan persentase kemiskinan di perkotaan dan perdesaan masingmasing mencapai $7,26 \%$ dan $13,47 \%$.

Dalam Undang-Undang Republik Indonesia No. 25 tahun 1992 pasal 1 tentang perkoperasian, menjelaskan bahwa koperasi adalah suatu badan usaha yang beranggotakan orang-seorang atau badan hukum koperasi dengan melandaskan kegiatannya berdasarkan prinsip koperasi sekaligus sebagai gerakan ekonomi rakyat yang berdasarkan atas asas kekeluargaan. Sebagai salah satu gerakan ekonomi rakyat, koperasi merupakan aktor pembangunan nasional yang bertujuan untuk menyejahterakan anggota pada khususnya dan rakyat pada umumnya.

Anggota pada dasarnya merupakan kekuatan utama yang dimiliki oleh koperasi. Salah satu ciri khas yang dimiliki anggota koperasi adalah identitas ganda yakni seorang anggota koperasi berperan sebagai pemilik dan juga pelanggan. Oleh karena itu, koperasi memerlukan partisipasi aktif dari anggotanya sebagaimana dijelaskan oleh Hendar dan Kusnadi (2005) bahwa partisipasi anggota sangat berpengaruh dan menentukan terhadap keberhasilan koperasi, karena partisipasi anggota merupakan unsur utama dan paling penting dalam mencapai keberhasilan koperasi.

Manfaat koperasi merupakan suatu nilai yang diberikan oleh koperasi kepada anggotanya baik berupa materiil maupun nonmateriil. Ropke (2003) menjelaskan bahwa koperasi tidak akan menarik bagi anggota, calon anggota dan masyarakat lainnya yang ingin menjadi anggota, karena hanya merasa memiliki kelebihan modal. Sebaliknya, koperasi akan sangat menarik bila koperasi dapat 
memberikan manfaat ekonomi bagi anggotanya. Oleh karena itu, tanpa kedua manfaat yang diberikan koperasi tersebut, maka koperasi akan sama seperti badan usaha lainnya.

Salah satu koperasi simpan pinjam di Lampung Tengah yang masih aktif dalam menjalankan unit usaha dan Rapat Anggota Tahunan (RAT) adalah Koperasi Simpan Pinjam (KSP) Subur Makmur Sejahtera yang terletak di Kecamatan Seputih Banyak. Pendirian koperasi ini dilatarbelakangi oleh banyaknya permintaan dari anggota Kelompok Tani Subur Makmur untuk mendirikan koperasi, agar dapat membantu pembiayaan usahatani mereka.

KSP Subur Makmur Sejahtera telah memiliki aset yang mencapai empat milyar rupiah. Prestasi tersebut tidak lepas dari kontribusi anggotanya yang terus ikut berpartisipasi aktif dalam organisasi, permodalan, dan bidang usaha koperasi. Namun demikian, fenomena di lapangan menggambarkan hal yang berbeda. Tingkat partisipasi anggota koperasi sangat bervariasi antara anggota satu dan lainnya. Walaupun partisipasi anggota di koperasi ini sudah terbilang cukup baik, tetapi masih terdapat anggota yang belum berpartisipasi secara aktif dalam menghadiri RAT, membayar simpanan wajib, dan memanfaatkan unit usaha koperasi.

Manfaat yang diberikan KSP Subur Makmur Sejahtera pada dasarnya dapat memengaruhi partisipasi anggotanya. Semakin besar manfaat yang diberikan oleh koperasi, semakin tinggi pula tingkat partisipasi anggota. Dengan aset serta unit usaha yang dimiliki, koperasi seharusnya dapat memberikan manfaat yang lebih besar kepada anggotanya. Berdasarkan masalah yang ada, maka penelitian ini bertujuan untuk mengetahui besarnya manfaat ekonomi yang diterima anggota, mengetahui manfaat nonekonomi yang dirasakan anggota, mengetahui tingkat partisipasi anggota, dan mengetahui faktor-faktor yang memengaruhi tingkat partisipasi anggota KSP Subur Makmur Sejahtera.

\section{METODE PENELITIAN}

Penelitian ini dilakukan di KSP Subur Makmur Sejahtera, Desa Sumber Baru, Kecamatan Seputih Banyak, Kabupaten Lampung Tengah dengan menggunakan metode survai. Pemilihan lokasi dilakukan secara sengaja (purposive) dengan pertimbangan bahwa koperasi tersebut merupakan salah satu koperasi yang bergerak di bidang pertanian dan masih aktif menjalankan RAT dan unit usahanya. Diperoleh 48 jumlah sampel dari total 125 anggota koperasi yang dihitung berdasarkan teori Isaac dan Michael dalam Sugiarto dkk (2003) dan dipilih dengan metode acak sederhana (simple random sampling). Pengambilan data dilakukan pada bulan JanuariFebruari 2018.

Data yang digunakan dalam penelitian ini adalah data primer dan data sekunder. Data primer yang digunakan seperti identitas anggota, manfaat ekonomi dan nonekonomi yang diterima dan dirasakan anggota, serta tingkat partisipasi anggota dalam menghadiri RAT, membayar simpanan wajib, dan memanfaatkan unit usaha koperasi yang seluruhnya diperoleh dari wawancara langsung dengan anggota koperasi, sedangkan data sekunder yang digunakan berupa jumlah koperasi aktif di Pulau Sumatera, perkembangan jenis koperasi aktif dan tidak aktif di Provinsi Lampung dan Kecamatan Seputih Banyak, serta laporan keuangan koperasi yang masing-masing diperoleh dari BPS, Dinas Koperasi dan UMKM Provinsi Lampung dan Kabupaten Lampung Tengah, serta KSP Subur Makmur Sejahtera.

Metode yang digunakan untuk menganalisis manfaat ekonomi koperasi adalah deskriptif kuantitatif. Manfaat ekonomi yang diterima anggota koperasi dilihat dari periode satu tahun terakhir yakni Februari 2017 hingga Februari 2018. Manfaat ekonomi koperasi dihitung dari manfaat ekonomi tunai dan manfaat ekonomi diperhitungkan. Manfaat ekonomi tunai berupa jumlah dari sisa hasil usaha dan tunjangan yang diterima anggota, sedangkan manfaat ekonomi diperhitungkan berupa selisih harga beli, harga sewa, dan harga reparasi di toko serta bengkel milik koperasi dan di luar koperasi.

Manfaat nonekonomi koperasi dianalisis menggunakan analisis deskriptif kuantitatif. Manfaat nonekonomi koperasi dilihat dari kepuasan anggota sebagai anggota koperasi dan terhadap pelayanan koperasi yang diukur menggunakan alat analisis Customer Satisfaction Index (CSI). Penentuan kepuasan diukur dengan menggunakan seperangkat pertanyaan tertutup dengan menggunakan skala likert dengan lima alternatif jawaban yakni sangat memuaskan (skor 5), memuaskan (skor 4), cukup memuaskan (skor 3), kurang memuaskan (skor 2), dan tidak memuaskan (skor 1). Tingkat kepuasan anggota sebagai anggota koperasi dilihat dari bagaimana koperasi dapat memenuhi tiga kebutuhan inti 
berdasarkan teori ERG Alderfer dalam Robbins dan Judge (2008) yakni keberadaan (existence), hubungan (relatedness), dan kemajuan (growth), sedangkan kepuasan terhadap pelayanan koperasi dilihat berdasarkan lima aspek yakni aspek fisik (tangibles), keandalan (reliability), daya tanggap (responsiveness), jaminan (assurance), dan empati (emphaty).

Sebelum digunakan, kuesioner terlebih dahulu diuji menggunakan uji validitas dan reliabilitas dengan bantuan IBM SPSS Statistics 20 dengan menguji jawaban dari 30 responden. Uji validitas merupakan pengujian yang dilakukan untuk mengukur sah atau valid tidaknya suatu kuesioner. Menurut Sufren dan Natanael (2013), nilai validitas dapat dikatakan baik, jika nilai corrected item dari total correlation bernilai lebih dari 0,20. Berbeda dengan uji validitas, uji reliabilitas dilakukan untuk mengetahui reliabilitas dari atribut-atribut yang diajukan pada responden dalam kuesioner. Apabila digunakan pada lokasi dan waktu yang berbeda, maka akan memperoleh hasil yang sama. Suatu instrumen dapat dikatakan reliabel, apabila nilai Cronbach's Alpha lebih besar dari 0,60 (Ghozali 2009).

Menurut Supranto (2006), Customer Satisfaction Index (CSI) merupakan salah satu metode yang digunakan untuk mengetahui tingkat kepuasan pelanggan secara keseluruhan dengan memperhatikan tingkat kepentingan dari atributatribut suatu produk atau jasa. Nilai maksimum untuk CSI adalah $100 \%$ dengan rentang nilai menurut yakni sangat puas $(81 \%-100 \%)$, puas (66\%-80\%), cukup puas (51\%-65\%), kurang puas (35\%-50\%), dan tidak puas (0\%-34\%). Berikut merupakan rumus perhitungan CSI:

$$
\mathrm{CSI}=\frac{(\mathrm{T})}{5(\mathrm{Y})} \times 100 \%
$$

Keterangan :

CSI $=$ Customer Satisfaction Index

$(\mathrm{T})=$ Total seluruh skor

$(\mathrm{Y})=$ Total seluruh nilai harapan (kepentingan)

5 = Nilai maksimum yang digunakan dalam skala pengukuran

Tingkat partisipasi anggota koperasi dianalisis dengan menggunakan metode deskriptif kuantitatif. Tingkat partisipasi anggota koperasi dilihat dari tingkat partisipasi dalam menghadiri RAT empat tahun terakhir yakni 2014 hingga 2017 (\%), membayar simpanan wajib periode Februari
2017-Februari 2018 (\%), dan pemanfaatan unit usaha koperasi selama satu tahun terakhir yakni Februari 2017-Februari 2018 (Rp/th). Tingkat partisipasi anggota koperasi dapat dihitung menggunakan rumus sebagai berikut :

Partisipasi dalam RAT (\%):

Jumlah Kehadiran dalam RAT Jumlah Total RAT

Partisipasi dalam membayar simpanan wajib (\%):

$\frac{\text { Simpanan W ajib (Rp/bln) }}{\text { Total Pelunasan Simpanan W ajib (Rp/bln) }} \times 100 \%$

Partisipasi dalam memanfaatkan unit usaha koperasi (Rp/th) :

$\sum$ (Barang Yang Dibeli $(\mathrm{Rp} / \mathrm{th})+$ Barang Yang Disewa (Rp/th) + Biaya Reparasi Mesin Di Bengkel Milik Koperasi (Rp/th).

Faktor-faktor yang memengaruhi tingkat partisipasi anggota koperasi dijawab dengan menggunakan alat analisis Seemingly Unrelated Regression (SUR). Model ini digunakan karena dapat menganalisis secara serentak tiga model regresi dengan variabel terikat (dependen) yang berbeda (partisipasi anggota koperasi dalam menghadiri RAT, membayar simpanan wajib, dan memanfaatkan pelayanan koperasi), namun dipengaruhi oleh variabel bebas (independen) yang sama. Berikut merupakan model persamaan yang digunakan :

$$
\begin{aligned}
& \mathrm{Y}_{1}=\alpha+\beta_{1} \mathrm{X}_{1}+\beta_{2} \mathrm{X}_{2}+\beta_{3} \mathrm{X}_{3}+\beta_{4} \mathrm{X}_{4}+\beta_{5} \mathrm{X}_{5}+\delta_{1} \mathrm{D}_{1}+ \\
& \delta_{2} \mathrm{D}_{2}+\delta_{3} \mathrm{D}_{3}+\delta_{4} \mathrm{D}_{4}+\delta_{5} \mathrm{D}_{5}+\mathrm{e} \\
& \mathrm{Y}_{2}=\alpha+\beta_{1} \mathrm{X}_{1}+\beta_{2} \mathrm{X}_{2}+\beta_{3} \mathrm{X}_{3}+\beta_{4} \mathrm{X}_{4}+\beta_{5} \mathrm{X}_{5}+\delta_{1} \mathrm{D}_{1}+ \\
& \delta_{2} \mathrm{D}_{2}+\delta_{3} \mathrm{D}_{3}+\delta_{4} \mathrm{D}_{4}+\delta_{5} \mathrm{D}_{5}+\mathrm{e} \\
& \mathrm{Y}_{3}=\alpha+\beta_{1} \mathrm{X}_{1}+\beta_{2} \mathrm{X}_{2}+\beta_{3} \mathrm{X}_{3}+\beta_{4} \mathrm{X}_{4}+\beta_{5} \mathrm{X}_{5}+\delta_{1} \mathrm{D}_{1}+ \\
& \delta_{2} \mathrm{D}_{2}+\delta_{3} \mathrm{D}_{3}+\delta_{4} \mathrm{D}_{4}+\delta_{5} \mathrm{D}_{5}+\mathrm{e} .
\end{aligned}
$$

Keterangan :

$\mathrm{Y}_{1}=$ Kehadiran anggota koperasi dalam 2014, 2015, 2016 dan 2017 (\% dari total RAT)

$\mathrm{Y}_{2}=$ Pembayaran simpanan wajib anggota koperasi tahun 2017 (\%)

$\mathrm{Y}_{3}=$ Pemanfaatan unit usaha oleh anggota koperasi (Rp/tahun)

$\alpha=$ Intersep

$\beta_{1}-\beta_{6}=$ Koefisien variabel bebas 


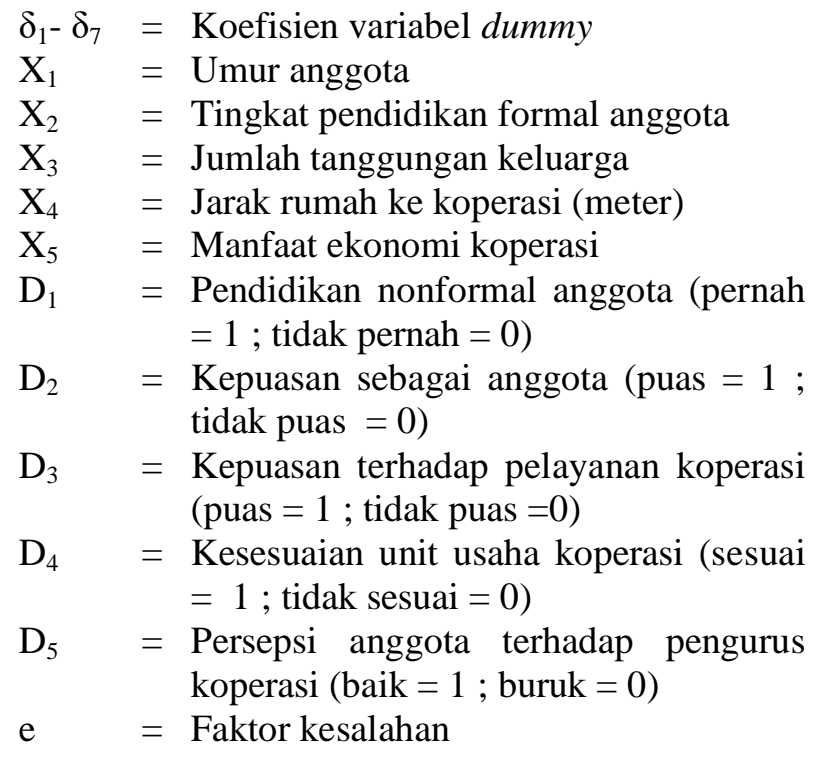

\section{HASIL DAN PEMBAHASAN}

\section{Karakteristik Responden}

Umur responden anggota koperasi umumnya berkisar di antara 46-55 tahun. Seluruh responden pernah menerima pendidikan formal dengan tingkat pendidikan terendah SD dan tertinggi SMA. Selain pendidikan formal, sebesar $75,00 \%$ responden pernah mengikuti pendidikan nonformal berupa pelatihan maupun penyuluhan. Responden umumnya bertempat tinggal di Kecamatan Seputih Banyak dengan jarak tempuh terdekat 100 meter dan terjauh 13.000 meter. Mayoritas responden memiliki jumlah tanggungan keluarga sebanyak 03 orang yakni sebesar $66,67 \%$. Sebesar $85,00 \%$ responden menganggap bahwa unit usaha yang disediakan oleh koperasi sudah sesuai, dan sebesar 90,00\% responden memiliki persepsi yang baik terhadap pengurus koperasi.

\section{Manfaat Ekonomi Koperasi}

Manfaat ekonomi koperasi dihitung dari jumlah manfaat ekonomi tunai dan diperhitungkan. Manfaat ekonomi koperasi yang diterima oleh anggota KSP Subur Makmur Sejahtera dapat dilihat dalam Tabel 1. Total rata-rata manfaat ekonomi tunai yang diperoleh anggota berupa Sisa Hasil Usaha (SHU) dan tunjangan yakni sebesar Rp402.063,04. Rata-rata SHU yang diterima anggota koperasi pada tahun 2017 yakni sebesar Rp327.063,04 yang dibagikan saat RAT. Jumlah SHU yang diberikan berbeda-beda sesuai dengan besar jasa usaha masing-masing anggota. Jumlah SHU terbesar yang diterima oleh anggota yakni Rp11.421.500,00 dan terkecil Rp28.100,00. Jumlah SHU terbesar yang diterima oleh anggota merupakan hasil pembagian $75,00 \%$ keuntungan dari mesin combine harvester milik pribadi yang disewakan di koperasi. Selain SHU, koperasi memberikan tunjangan dalam bentuk paket sembako yakni sebesar Rp75.000,00 yang terdiri dari gula, minyak goreng, teh, dan sebagainya. Tunjangan diberikan setiap tahun yakni menjelang Hari Raya Idul Fitri kepada seluruh anggota dengan jumlah yang sama.

Manfaat ekonomi diperhitungkan berasal dari selisih harga pelayanan pembelian di toko sarana produksi, penyewaan mesin combine harvester, dan reparasi mesin di bengkel milik koperasi. Sarana produksi yang dibeli oleh responden umumnya berupa pupuk (urea, SP36, NPK, KCl), pestisida (insektisida, herbisida, fungisida, dan rodentisida) berbagai merek. Manfaat ekonomi diperhitungkan tertinggi diperoleh dari pembelian di toko sarana produksi milik koperasi yakni sebesar Rp230.750,00, sedangkan terendah diperoleh dari pemanfaatan unit usaha bengkel mesin pertanian yakni sebesar Rp11.968,75. Hal ini terjadi karena berdasarkan penelitian yang dilakukan, hanya terdapat dua anggota yang memiliki mesin combine harvester untuk dapat memanfaatkan unit usaha bengkel. Anggota umumnya memanfaatkan jasa bengkel berupa penggantian oli mesin, reparasi spare part mesin (penggantian bearing, gear bintang, as gear box) dan sebagainya.

Manfaat ekonomi koperasi total yang diterima oleh anggota KSP Subur Makmur Sejahtera sebesar Rp789.052,62. Jumlah tersebut lebih rendah jika dibandingkan dengan manfaat ekonomi koperasi yang diterima oleh anggota Koperasi Serba Usaha Peternak Motivasi Doa Ikhtiar Tawakkal dalam penelitian Jalika, Lestari, dan Suryani (2016) tentang evaluasi keberhasilan koperasi yang mencapai Rp2.665.013,33 untuk anggota yang memiliki 0-5 ekor sapi, Rp4.195.266,67 untuk 6-10 ekor sapi, dan Rp 5.801.323,81 untuk 11-15 ekor sapi.

\section{Manfaat Nonekonomi Koperasi}

Manfaat nonekonomi koperasi dihitung menggunakan Customer Satisfaction Index (CSI). CSI merupakan alat analisis yang dapat mengukur tingkat kepuasan anggota koperasi secara keseluruhan dengan memperhatikan tingkat kepentingan dan kinerja atribut yang dijadikan indikator. Hasil perhitungan CSI kepuasan sebagai anggota koperasi dan terhadap pelayanan koperasi masing-masing sebesar $73,16 \%$ dan $69,61 \%$. 
Berdasarkan nilai CSI yang diperoleh, dapat disimpulkan bahwa tingkat kepuasan anggota KSP Subur Makmur Sejahtera sebagai anggota koperasi dan terhadap pelayanan koperasi keduanya berada dalam kategori puas. Hal ini menunjukkan bahwa KSP Subur Makmur Sejahtera telah memberikan kepuasan terhadap anggotanya. Oleh karena itu, koperasi harus mempertahankan kinerjanya sehingga dapat terus memberikan kepuasan terhadap anggotanya.

Hasil penelitian ini sejalan dengan penelitian Seta, Lestari, dan Situmorang (2015) tentang manfaat ekonomi dan nonekonomi koperasi, serta Putri, Lestari, dan Sayekti (2017) tentang kinerja dan strategi pengembangan koperasi yang menyatakan bahwa nilai CSI yang diperoleh dalam kedua penelitian tersebut masing-masing sebesar $70,80 \%$ dan 70,57\% yang artinya tingkat kepuasan anggota Koperasi Gunung Madu dan Primkopti Pesawaran keduanya berada dalam kategori puas.

\section{Tingkat Partisipasi Anggota Koperasi}

Tingkat partisipasi anggota koperasi diukur berdasarkan partisipasi anggota dalam organisasi, permodalan, dan bidang usaha. Tingkat partisipasi anggota KSP Subur Makmur Sejahtera dalam menghadiri RAT termasuk dalam kategori sedang yakni dengan persentase rata-rata sebesar $74,48 \%$ yang termasuk dalam kategori sedang. Namun demikian, angka tingkat partisipasi yang cukup tinggi tidak diiringi dengan keaktifan anggota dalam memberikan suara yakni berupa kritik, saran, ataupun pertanyaan. Berdasarkan penelitian yang dilakukan, masih banyak anggota yang tidak memberikan suara dalam RAT. Padahal, suara dari anggota sejatinya sangat diperlukan untuk membangun koperasi yang lebih baik.

Tabel 1. Rata-rata manfaat ekonomi koperasi yang diterima oleh anggota KSP Subur Makmur Sejahtera satu tahun terakhir

\begin{tabular}{lr}
\hline \multicolumn{1}{c}{ Manfaat Ekonomi Koperasi } & Jumlah (Rp/th) \\
\hline Tunai & $327.063,04$ \\
SHU & $75.000,00$ \\
\hline Tunjangan & $402.063,04$ \\
\hline Total MEK tunai/tahun & \\
\hline Diperhitungkan & $230.750,00$ \\
Harga pelayanan pembelian (toko) & $144.270,83$ \\
Harga pelayanan penyewaan (mesin & \\
combine harvester) & $11.968,75$ \\
\hline Harga pelayanan bengkel & $386.989,58$ \\
\hline Total MEK diperhitungkan/tahun & $789.052,62$ \\
\hline Total MEK/tahun &
\end{tabular}

Hal ini disebabkan mayoritas dari anggota koperasi cenderung langsung menyetujui hal-hal yang diungkapkan oleh pengurus, baik laporan pertanggungjawaban maupun rencana-rencana ke depan yang akan dilaksanakan oleh KSP Subur Makmur Sejahtera.

Tingkat partisipasi anggota dalam membayar simpanan wajib memiliki persentase rata-rata sebesar $83,51 \%$ yang termasuk dalam kategori tinggi. Simpanan wajib yang dibayarkan anggota KSP Subur Makmur Sejahtera setiap bulannya yakni sebesar Rp30.000,00. Kesadaran anggota yang tinggi tidak terlepas dari usaha pengurus yang selalu mengingatkan dan mendorong anggotanya untuk terus membayar simpanan wajib guna mempertahankan modal yang dimiliki oleh KSP Subur Makmur Sejahtera. Namun demikian, masih banyak anggota koperasi yang belum berpartisipasi dengan baik dalam membayar simpanan wajib dan tidak membayar tepat waktu. Hal ini mendorong pengurus koperasi untuk lebih aktif mengingatkan seluruh anggotanya demi kemajuan koperasi bersama.

Rata-rata tingkat partisipasi anggota dalam memanfaatkan unit usaha koperasi dalam satu tahun terakhir yakni sebesar Rp2.798.143,75 sehingga tingkat partisipasi anggota dalam memanfaatkan unit usaha koperasi dapat dikatakan berada dalam kategori rendah. Nilai rata-rata pemanfaatan unit usaha yang tinggi berada dalam kategori rendah, karena terjadi interval yang terpaut jauh antara partisipasi tertinggi dan terendah di koperasi. Nilai partisipasi tertinggi yakni sebesar Rp9.013.000,00 dan terendah sebesar Rp234.000,00. Anggota yang berada dalam kategori tingkat partisipasi tinggi umumnya memiliki lahan yang cukup luas serta adapula yang memiliki mesin combine harvester secara pribadi. Oleh karena itu, hal tersebut mendorong mereka untuk berpartisipasi lebih dalam memanfaatkan unit usaha koperasi yakni dengan membeli sarana produksi di toko milik koperasi dalam jumlah lebih besar dan dapat memanfaatkan jasa bengkel milik koperasi.

Banyaknya anggota yang berpartisipasi dalam memanfaatkan unit usaha koperasi juga disebabkan oleh kebijakan pengurus yang memberikan keringanan kepada anggota, sehingga anggota dapat berhutang dengan melakukan sistem yarnen atau bayar panen. Selain harga yang lebih murah, petani anggota juga tidak perlu membayar uang muka untuk berhutang di koperasi, akan tetapi petani dapat membayarnya setelah panen. Kondisi 
seperti ini yang tidak diperoleh petani ketika membeli input produksi di toko lain di luar koperasi.

Hasil penelitian ini berbeda dengan penelitian yang dilakukan oleh Martiani, Lestari, dan Murniati (2016) tentang tingkat partisipasi, struktur pendapatan dan kesejahteraan anggota koperasi yang menyebutkan bahwa rata-rata tingkat partisipasi anggota Koperasi Tani Surya Sekawan dalam menghadiri RAT dan melunasi simpanan wajib masing-masing sebesar $98,68 \%$ dan $100,00 \%$. Selain itu, rata-rata tingkat partisipasi anggota dalam memanfaatkan unit usaha koperasi yakni sebesar Rp1.589.903,85. Ketiga rata-rata tingkat partisipasi anggota tersebut berada dalam kategori tinggi.

\section{Faktor-faktor yang Memengaruhi Tingkat Partisipasi Anggota Koperasi}

Faktor-faktor yang memengaruhi tingkat partisipasi anggota koperasi dalam menghadiri RAT, membayar simpanan wajib, dan memanfaatkan unit usaha koperasi dianalisis menggunakan model Seemingly Unrelated Regression (SUR) dengan menggunakan variabel bebas yang sama untuk setiap model persamaan. Hasil analisis faktor-faktor yang memengaruhi tingkat partisipasi anggota koperasi disajikan dalam Tabel 2 hingga Tabel 4.

Berdasarkan Tabel 2, diperoleh koefisien determinasi (R-squared) sebesar $79,04 \%$ yang artinya bahwa $79,04 \%$ tingkat partisipasi anggota koperasi dalam menghadiri RAT dapat dijelaskan oleh variasi variabel umur, pendidikan formal, jumlah tanggungan keluarga, jarak, manfaat ekonomi koperasi, pendidikan nonformal, kepuasan sebagai anggota, kepuasan terhadap pelayanan koperasi, kesesuaian unit usaha, dan persepsi terhadap pengurus koperasi yang dimasukkan ke dalam model, sedangkan sisanya sebesar 20,96\% dapat dijelaskan oleh variabel lain yang tidak dimasukkan dalam model.

Faktor-faktor yang memengaruhi secara positif dan nyata terhadap partisipasi anggota KSP Subur Makmur Sejahtera dalam menghadiri RAT adalah umur, pendidikan formal, jumlah tanggungan keluarga, pendidikan nonformal, kepuasan terhadap pelayanan koperasi, dan persepsi terhadap pengurus, sedangkan jarak berpengaruh secara negatif. Ketika umur anggota semakin tua, jumlah tanggungan keluarga semakin banyak, jarak rumah anggota ke koperasi semakin dekat, anggota pernah menerima pendidikan nonformal, dan merasa puas terhadap pelayanan koperasi, serta memiliki persepsi yang baik terhadap pengurus, maka semakin tinggi tingkat partisipasi anggota dalam menghadiri RAT.

Berbeda dengan penelitian yang dilakukan Lestari, Masyhuri, dan Mulyo (2011) tentang partisipasi petani padi anggota Koptan dan KUD di Provinsi Lampung yang menyatakan bahwa pengalaman berkoperasi, jumlah tanggungan keluarga, manfaat ekonomi koperasi, pendidikan nonformal, dan kepuasan anggota terhadap pelayanan koperasi mempengaruhi partisipasi anggota KUD di Provinsi Lampung, sedangkan pendapatan rumah tangga dan manfaat ekonomi koperasi mempengaruhi partisipasi anggota Koptan di Provinsi Lampung dalam menghadiri RAT. Manfaat ekonomi yang tinggi, jumlah tanggungan keluarga yang banyak, anggota merasa puas terhadap pelayanan koperasi, dan pernah menerima pendidikan nonformal dapat meningkatkan partisipasi anggota koperasi dalam menghadiri RAT.

Pada Tabel 3 dapat dilihat bahwa nilai $R$-squared sebesar $80,81 \%$ yang artinya bahwa $80,81 \%$ tingkat partisipasi anggota koperasi dalam membayar simpanan wajib dapat dijelaskan oleh variasi variabel umur, pendidikan formal, jumlah tanggungan keluarga, jarak, manfaat ekonomi koperasi, pendidikan nonformal, kepuasan sebagai anggota, kepuasan terhadap pelayanan koperasi, kesesuaian unit usaha, dan persepsi terhadap pengurus koperasi yang dimasukkan ke dalam model, sedangkan sisanya sebesar $19,19 \%$ dapat dijelaskan oleh variabel lain yang tidak dimasukkan dalam model.

Tabel 2. Hasil regresi faktor-faktor yang memengaruhi partisipasi anggota dalam menghadiri RAT

\begin{tabular}{llrc}
\hline \multicolumn{1}{c}{ Variabel } & \multicolumn{1}{c}{ Coefficient } & $t$-Stats & Prob. \\
\hline Konstanta & $-35,9876$ & $-1,2370$ & 0,2187 \\
Umur & $0,8869 * *$ & 2,0597 & 0,0418 \\
Pd. Form & $4,2283 * * *$ & 3,6201 & 0,0004 \\
JTK & 2,4767 & 1,2851 & 0,2014 \\
Jarak & $-0,0021 * * *$ & $-2,9443$ & 0,0039 \\
MEK & $-9,2300$ & $-0,8048$ & 0,4227 \\
Pd. Nonf & $18,2423 * * *$ & 3,0155 & 0,0032 \\
Kep. Ang & 2,1371 & 0,2823 & 0,7782 \\
Kep. Lay & $8,1975 *$ & 1,7023 & 0,0915 \\
Kesesuaian & 0,8738 & 0,1717 & 0,8640 \\
Persepsi & $14,3511 * * *$ & 2,7194 & 0,0076 \\
\hline R-squared & & & 0,7904 \\
Adjusted $R$-Squared & & 0,7338 \\
\hline Keterangan : *** : Signifikan pada 99\% & $*$ Signifikan pada $90 \%$ \\
\multicolumn{2}{r}{ : Signifikan pada 95\% } & &
\end{tabular}


Faktor-faktor yang memengaruhi secara positif dan nyata terhadap partisipasi anggota KSP Subur Makmur Sejahtera dalam membayar simpanan wajib adalah pendidikan formal, kepuasan sebagai anggota, dan kepuasan terhadap pelayanan koperasi, sedangkan jarak berpengaruh secara negatif. Ketika jarak rumah anggota koperasi ke koperasi semakin dekat, pendidikan formal yang diterima semakin tinggi, anggota merasa puas sebagai anggota koperasi dan terhadap pelayanan koperasi maka semakin tinggi tingkat partisipasi anggota dalam membayar simpanan wajib.

Hasil penelitian ini berbeda dengan penelitian yang dilakukan oleh Lestari, Masyhuri, dan Mulyo (2011) tentang partisipasi petani padi anggota Koptan dan KUD di Provinsi Lampung yang menyatakan bahwa umur, pengalaman berkoperasi, manfaat ekonomi, dan jarak memengaruhi anggota KUD dan Koptan di Provinsi Lampung dalam membayar simpanan wajib. Umur anggota koperasi yang semakin muda, manfaat ekonomi koperasi yang semakin tinggi, serta jarak rumah anggota ke koperasi yang semakin jauh akan meningkatkan partisipasi anggota koperasi dalam membayar simpanan wajib.

Berdasarkan Tabel 4, diperoleh nilai $R$-squared sebesar $70,08 \%$ yang artinya bahwa sebesar $70,08 \%$ tingkat partisipasi anggota koperasi dalam memanfaatkan unit usaha dapat dijelaskan oleh variasi variabel umur, pendidikan formal, jumlah tanggungan keluarga, jarak, manfaat ekonomi koperasi, pendidikan nonformal, kepuasan sebagai anggota, kepuasan terhadap pelayanan koperasi, kesesuaian unit usaha, dan persepsi terhadap pengurus koperasi yang dimasukkan ke dalam model, sedangkan sisanya sebesar $29,92 \%$ dapat dijelaskan oleh variabel lain yang tidak dimasukkan dalam model.

Faktor-faktor yang memengaruhi secara positif dan nyata terhadap partisipasi anggota KSP Subur Makmur Sejahtera dalam memanfaatkan unit usaha adalah umur, pendidikan formal, jumlah tanggungan keluarga, dan manfaat ekonomi koperasi, sedangkan jarak dan pendidikan nonformal berpengaruh secara negatif. Ketika semakin tua umur anggota, semakin tinggi pendidikan formal yang diterima, semakin banyak jumlah tanggungan keluarga, semakin besar manfaat ekonomi koperasi yang diterima, dan semakin dekat jarak rumah anggota ke koperasi, serta anggota tidak pernah menerima pendidikan nonformal maka akan meningkatkan partisipasi anggota dalam memanfaatkan unit usaha koperasi.
Tabel 3. Hasil regresi faktor-faktor yang memengaruhi partisipasi anggota dalam membayar simpanan wajib

\begin{tabular}{|c|c|c|c|}
\hline Variabel & Coefficient & $t$-Stats & Prob. \\
\hline Konstanta & $3.194,8010$ & 1,6214 & 0,1078 \\
\hline Umur & 33,2740 & 1,1409 & 0,2564 \\
\hline Pd. Form & $214,3181 * * *$ & 2,7093 & 0,0078 \\
\hline JTK & 153,3382 & 1,1747 & 0,2426 \\
\hline Jarak & $-0,2032 * * *$ & $-4,2755$ & 0,0000 \\
\hline MEK & $-8,2000$ & $-0,1056$ & 0,9161 \\
\hline Pd. Nonf & 443,2400 & 1,0818 & 0,2817 \\
\hline Kep. Ang & $879,6729 *$ & 1,7156 & 0,0890 \\
\hline Kep. Lay & $1176,8880 * * *$ & 3,6085 & 0,0005 \\
\hline Kesesuaian & $-229,4628$ & $-0,6658$ & 0,5069 \\
\hline Persepsi & 424,8331 & 1,1886 & 0,2371 \\
\hline \multicolumn{2}{|l|}{$R$-squared } & & 0,8082 \\
\hline \multicolumn{2}{|c|}{ Adjusted R-Squared } & & 0,7563 \\
\hline \multicolumn{4}{|c|}{ Keterangan : } \\
\hline \multicolumn{4}{|c|}{ *** : Signifikan pada $99 \%$} \\
\hline
\end{tabular}

Tabel 4. Hasil regresi faktor-faktor yang memengaruhi partisipasi anggota dalam memanfaatkan unit usaha

\begin{tabular}{lcrl}
\hline \multicolumn{1}{c}{ Variabel } & Coefficient & \multicolumn{1}{c}{$t$-Stats } & Prob. \\
\hline Konstanta & $-3.184 .881,00$ & $-1,2861$ & 0,2011 \\
Umur & $64.068,33 *$ & 1,7479 & 0,0832 \\
Pd. Form & $200.901,80 * *$ & 2,0208 & 0,0457 \\
JTK & $344.095,10^{* *}$ & 2,0975 & 0,0382 \\
Jarak & $-125,7294 * *$ & $-2,1045$ & 0,0376 \\
MEK & $0,5503 * * *$ & 5,6367 & 0,0000 \\
Pd. Nonf & $-880.679,4000 *$ & $-1,7103$ & 0,0900 \\
Kep. Ang & $877.333,7000$ & 1,3614 & 0,1761 \\
Kep. Lay & $96.636,0800$ & 0,2358 & 0,8141 \\
Kesesuaian & $-552.099,6000$ & $-1,2745$ & 0,2051 \\
Persepsi & $468.105,6000$ & 1,0421 & 0,2996 \\
\hline$R$-squared & & & 0,7008 \\
\hline \multicolumn{1}{c}{ Adjusted $R$-Squared } & & 0,6200 \\
\hline Keterangan : & \multirow{2}{*}{ : Signifikan pada $90 \%$} \\
*** Signifikan pada $99 \%$ & & \\
** : Signifikan pada 95\% &
\end{tabular}

Hasil penelitian ini berbeda dengan penelitian yang dilakukan oleh Lestari, Masyhuri, dan Mulyo (2011) tentang partisipasi petani padi anggota Koptan dan KUD di Provinsi Lampung yang menyatakan bahwa faktor-faktor yang memengaruhi anggota KUD dan Koptan di Provinsi Lampung dalam memanfaatkan unit usaha koperasi adalah jumlah tanggungan keluarga, jumlah kerjasama koperasi, dan SHU. Jumlah tanggungan keluarga yang semakin banyak, jarak yang semakin jauh, dan anggota merasa sesuai dengan unit usaha koperasi akan meningkatkan partisipasi anggota koperasi dalam memanfaatkan unit usaha koperasi. 


\section{KESIMPULAN}

Manfaat ekonomi koperasi yang diterima oleh anggota adalah sebesar Rp789.052,62 yang termasuk dalam kategori besar. Manfaat nonekonomi yang dirasakan oleh anggota karena menjadi anggota koperasi dan terhadap pelayanan koperasi berada dalam kategori puas. Tingkat partisipasi anggota koperasi dalam menghadiri RAT, membayar simpanan wajib, dan memanfaatkan unit usaha koperasi masing-masing berada dalam kategori sedang, tinggi, dan rendah. Umur, pendidikan formal, pendidikan nonformal, kepuasan terhadap pelayanan koperasi, persepsi terhadap pengurus, dan jarak rumah anggota ke koperasi memengaruhi tingkat partisipasi anggota dalam menghadiri RAT, sedangkan pendidikan formal, kepuasan anggota, kepuasan terhadap pelayanan, dan jarak memengaruhi tingkat partisipasi anggota dalam membayar simpanan wajib dan umur, pendidikan formal, jumlah tanggungan keluarga, manfaat ekonomi, jarak dan pendidikan nonformal memengaruhi tingkat partisipasi anggota dalam memanfaatkan unit usaha koperasi.

\section{DAFTAR PUSTAKA}

BPS [Badan Pusat Statistik]. 2017. Angka Kemiskinan Menurut Provinsi. Badan Pusat Statistik. Jakarta.

Ghozali I. 2009. Aplikasi Analisis Multivariate dengan Program SPSS, Edisi Ke-4. Universitas Diponegoro. Semarang.

Hendar dan Kusnadi. 2005. Ekonomi Koperasi. Lembaga Penerbit Fakultas Ekonomi Universitas Indonesia. Jakarta.

Jalika, TU, Lestari DAH, dan Suryani A. 2016. Evaluasi keberhasilan Koperasi Serba Usaha Peternak Motivasi Doa Ikhtiar Tawakkal (KSUP MDIT) Kabupaten Tanggamus, Lampung berdasarkan pendekatan tripartite. JIIA, 4 (4) : 414-422. http://jurnal.fp.unila.
ac.id/index.php/JIA/article/view/1524/1378 .

[5 Agustus 2018].

Lestari DAH, Masyhuri, dan Mulyo JH. 2011. Partisipasi petani padi anggota Koptan dan KUD di Provinsi Lampung. Jurnal Ilmiah ESAI, 5(3). http://jurnal.polinela.ac.id/index. php/ESAI/article/view/1019/705. [12 Juli 2018].

Martiani D, Lestari DAH, dan Murniati K. 2016. Tingkat partisipasi, struktur pendapatan,dan kesejahteraan anggota Koperasi Tani Surya Sekawan Desa Banyuwangi Kecamatan Banyumas, Pringsewu. JIIA, 4(2): 186-191. http://jurnal.fp.unila.ac.id/index.php/JIA/articl e/view/1236/1133. [24 April 2018].

Putri RM, Lestari DAH, dan Sayekti WD. 2017. Kinerja dan strategi pengembangan Primkopti Kabupaten Pesawaran. JIIA, 5(2): 184-191. http://jurnal.fp.unila.ac.id/index.php/JIA/articl e/view/1657/1483.[23 April 2018]

Robbins SP dan Judge TA. 2008. Perilaku Organisasi. Salemba Empat. Jakarta.

Ropke J. 2003. Ekonomi Koperasi (Teori dan Manajemen) Terjemahan Sri Djatnika $S$. Arifin. Salemba Empat. Jakarta.

Seta AP, Lestari DAH, dan Situmorang S. 2016. Manfaat ekonomi dan nonekonomi Koperasi Gunung Madu di PT Gunung Madu Plantations Kabupaten Lampung Tengah. JIIA, 4(2): 168-177. http://jurnal.fp.unila. ac.id /index.php/JIA/article/view/1234/1131. [25 April 2018]

Sufren dan Natanael Y. 2013. Mahir Menggunakan SPSS secara Otodidak. PT Elex Media Komputindo. Jakarta.

Sugiarto, Siagian D, Sunaryanto LT, dan Oetomo DS. 2003. Teknik Sampling. PT Gramedia Pustaka Utama. Jakarta.

Supranto J. 2006. Pengukuran Tingkat Kepuasan Pelanggan Untuk Menaikan Pangsa Pasar. Rineka Cipta. Jakarta.

Undang-Undang Perkoperasian No. 25 tahun 1992. 2014. Sinar Grafika. Jakarta. 